\title{
ГОРИЗОНТЫ ПСИХОЛОГИИ
}

\author{
Е.В. Грязнова
}

DOI: 10.7256/2070-8955.2013.04.8

\section{ИДЕНТИФИКАЦИЯ ЧЕЛОВЕКА В ИНФОРМАЦИОННОЙ РЕАЛЬНОСТИ}

\begin{abstract}
Аннотация: В условиях информационного общества социальный опыт уже не может передаваться только традииионными методами. Современный человек вынужден с раннего возраста погружаться в информационнокомпьютерное взаимодействие, происходящее в поле информационной реальности, создаваемой современными компьютерными системами. Таким образом, уже в первый период соииализации тичности - идентификаиии все интенсивней используются современные компьютерные технологии. В статье рассматриваются возможные негативные последствия идентификации, когда соиииальный опыт передается не через реального субъекта соииализации, а через информационные квазисубъекты, создаваемые современными компьютерно-информационными системами.

Ключевые слова: педагогика, информационно-компьютерная социализация, информационно-компьютерное взаимодействие, идентификация, информационная реальность, дочкольник, компьютеризированное образование, компьютеризированное обучение, компьютеризированное воспитание, информационно-компьютерная культура.
\end{abstract}

Данная статья посвящена разработке достаточной сложной и актуальной сегодня проблемы, которой мы занимаемся уже более десяти лет - проблемы информационно-компьютерной социализации личности. Социализация, реализуемая с помощью современных информационных технологий, является неотъемлемым элементом информационного общества. Она имеет, несомненно, свои плюсы. Но при этом возникают и достаточно серьезные проблемы. Так, уже сейчас зависимость от интернета превращается в Южной Корее в одно из основных заболеваний, особенно среди молодежи. В 2009 г. в США появилась первая клиника по лечению данной зависимости.

Чтобы не решать проблемы постфактум, необходимо понять причины их возникновения и своевременно принять меры. Поэтому мы предлагаем проанализировать механизмы первой и самой важной ступени информационно-компьютерной социализации личности - идентификации, с целью выявления ее возможных негативных проявлений.

\section{1. Основные понятия}

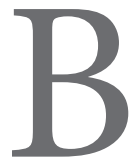

самом общем виде социализацию можно представить как процесс усвоения индивидом определенной системы знаний, норм и ценностей, позволяющих ему функционировать в качестве полноправного члена общества. В то же время социализация, как процесс, включает в себя не только этапы, когда человек перенимает социальный опыт, но еще и период его жизни, когда он его реализует. Реализация социального опыта - это и есть качественный показатель личности. В связи с этим социализация представляется как интегральный трехуровневый процесс, являющийся важнейшим механизмом педагогической деятельности:

- идентификация (становление Человека);

- индивидуализация (становление Индивидуальности);

- персонификация (становление Личности) ${ }^{1}$.

Процесс идентификации раскрывает «врастание» индивида в общество, освоение им достижений материальной и духовной культуры, присущих данному обществу. На этом этапе формируется понятие «Мы», когда индивид «растворяет» себя с теми, кто его окружает: он, как все.

Индивидуализация позволяет развивать в индивиде то, что делает его непохожим на других, то, что выделяет его из окружения ему подобных, то, что формирует его самостоятельность, т.е. то, что он есть сам по себе. Она зависит не столько от общества, сколько от самого человека: его воли, потребности, интересов. Появляется «Я», как альтернатива «Мы».

1 Зеленов Л.А. Становление личности. Горький, 1989. С. 27. 


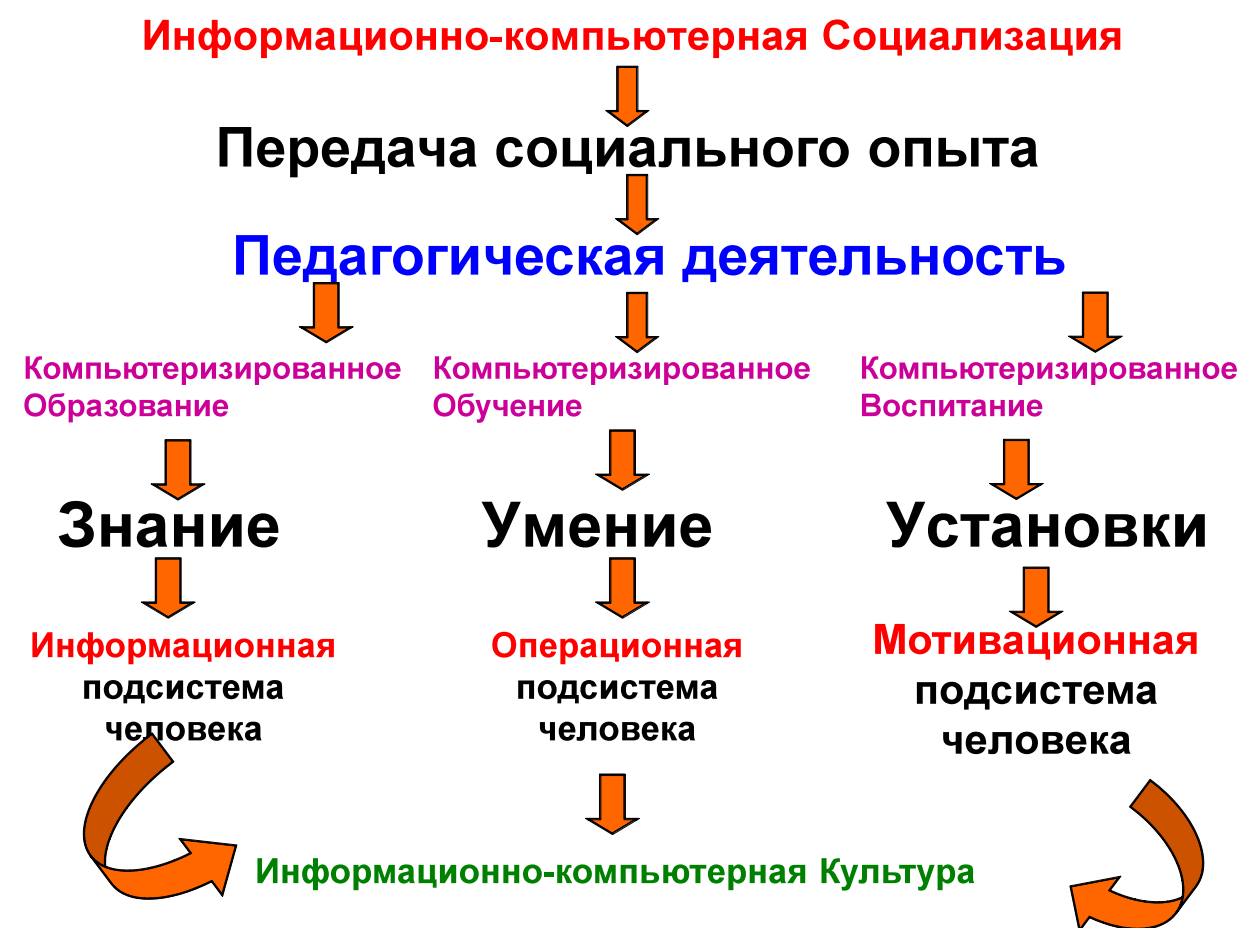

Персонализация интегрирует предшествующие ступени развития человека, характеризуя его со стороны социальной активности, т.е. он реализует все, что знает и умеет, что и выражает сущность в понятии «личность». Формируется единство «Я - Мы».

Социализация - это не механическая передача суммы знаний, умений и установок. Процесс включения в современный поток информации из прошлого носит сугубо селективный характер. Новое общество, новая социальная среда тщательно отбирают из опыта прошлого те элементы, которые прямо или косвенно будут содействовать их прогрессу, стремясь исключить то, что не способствует дальнейшему развитию. В процессе социальной практики всегда происходит отбор наиболее значимого для жизни общества социального знания, умения иустановок (социальный опыт). В результате формируются три подсистемы человека:

- знания - информационная подсистема,

- умения - операционная подсистема,

- установки - мотивационная подсистема.

Следует отметить также, что формирование социального опыта происходит с помощью трех функций педагогической деятельности:

- образование - передача и освоение знаний, информационного опыта,

- обучение - передача и освоение умений, операционального опыта,

- воспитание - передача и освоение установок, мотивационного опыта.
Форма социализации личности исторически изменчива, т.к. смена цивилизаций основана на преобразовании культуры, изменении ее аспектов, одним из которых оказывается эволюция знакового (семиотического) опосредования социального взаимодействия. Согласно культурно-исторической теории деятельности, разработанной школой Л.С. Выготского, существенным стимулом для психического развития является внешне орудийная деятельность человека. Наиболее значительное место Л.С. Выготский в своих теоретических построениях отводил именно семиотическим орудиям деятельности - знакам ${ }^{2}$. Современные информационные технологии оказываются в ряду подобных знаковых систем. Какие же изменения в социализацию личности они вносят?

Первое, на что следует обратить внимание - это сама форма социального взаимодействия, которая оказывается в основе процесса социализации в период существования различных цивилизаций. Второе - качественные и количественные изменения социальной информации, лежащей в основе социального взаимодействия. И, третье, - это изменение информационных процессов, без которых невозможна циркуляция социальной информации, а, следовательно, и существование социального взаимодействия.

В условиях информационного общества одной из основных форм социального взаимодействия

\footnotetext{
2 Выготский Л.С. Собр. соч.: в 6 т. М.: Педагогика, 1982-1984.
} 


\section{Горизонты психологии}

оказывается компьютеризированное информационное взаимодействие, спецификой которого является информационный способ существования всех его элементов: субъекта, объекта, средств, условий и т.п. В результате человек развивается и живет в новом для него виде реальности - информационной. Специфика такой реальности - наличие информационных объектов, коренным образом отличающихся от объектов материального мира, к которым адаптирован человек. Отличительной же особенностью компьютеризированного информационного взаимодействия от других видов социального информационного взаимодействия оказывается наличие в его составе интерактивных информационных квазисубъектов, способных обладать различной степенью субъектности и исполнять роль социального субъекта ${ }^{3}$.

Учитывая структурные изменения традиционной формы социализации личности, а именно, появление в ней информационных объектов и квазисубъектов, создаваемых компьютерными системами, можно определить информационно-компьютерную социализацию личности как процесс передачи (усвоения) социального опыта, происходящий в поле информационной реальности, создаваемой компьютерными системами.

На современном этапе развития общества можно говорить о компьютеризированных формах, как социального взаимодействия, так и информационной реальности, на основании которых и формируется информационно-компьютерная культура.

\section{2. Идентификация человека при информационно-компьютерной социализации}

В работах В.В. Давыдова, периоды жизни ребенка, охватывающие этап идентификации, представлены следующим образом:

1. Непосредственно эмоциональное общение присуще ребенку от рождения до года. У него формируется потребность в общении с другими людьми, эмоциональное отношение к ним, хватание как основа человеческих действий с вещами.

2. Предметно-манипулятивная деятельность является ведущей для ребенка от 1 года до 3 лет. Осуществляя эту деятельность (первоначально в сотрудничестве со взрослыми), ребенок воспроизводит общественно выработанные способы действия с вещами; у него возникает речь, смысловое обозначение вещей, обобщенно-категориальное восприятие предметного мира

\footnotetext{
3 Грязнова Е.В. Виртуально-информационная реальность в си-
} стеме «Человек - Универсум». Н. Новгород: ННГУ, 2006. 255 с. и наглядно-действенное мышление. Центральным новообразованием этого возраста является возникновение у ребенка сознания, выступающего для других в виде собственного детского «я».

3. Игровая деятельность наиболее доминируетуребенка от 3 до 6 лет. В процессе ее у него формируется воображение и символическая функция, ориентация на общий смысл человеческих отношений и действий; происходит выделение в них моментов соподчинения и управления, а также складываются обобщенные переживания и осмысленная ориентация в них ${ }^{4}$.

Данная периодизация наглядно демонстрирует тот факт, что в основе развития личности ребенка оказывается смена типа деятельности. Изучая этот феномен, Л.С. Выготский писал: «На каждой данной возрастной ступени мы всегда находим центральное новообразование, как бы ведущее перестройку всей личности ребенка на новой основе» ${ }^{5}$. Согласно А.Н. Леонтьеву, ведущая деятельность обуславливает главнейшие изменения особенностей ребенка в том или ином периоде развития. Ее характеризуют следующие признаки: 1) от нее ближайшим образом зависят основные психические изменения ребенка в данный возрастной период, 2) в ней возникают и дифференцируются другие виды деятельности, 3) в ней формируются и перестраиваются частные психические процессы ${ }^{6}$.

Исходя из выше сказанного, видно, что духовные свойства будущей личности закладываются в раннем детстве, через контактирование ребенка с окружающим миром, когда образование, воспитание и обучение происходят на уровне обыденного сознания. Иначе говоря, на данном этапе знания, умения и установки формируются стихийно, теоретически неосмысленно. Социальный опыт ребенок накапливает через поступки, осмысление которых происходит на эмоциональном уровне, где самым важным каналом контактирования оказывается сенсорный канал ощущения. Маленький ребенок благодаря чувственным контактам, эмоционально реагируя на них, вырабатывает такие свойства, как доверчивость, восприимчивость, неосознанное подражание, образное запоминание и т.п. Ребенок в основном через сенсорное восприятие получает разного рода информацию, которая отражается в его сознании сначала в виде представлений, а затем и понятий, оказывая влияние на развитие его психики и способностей.

\footnotetext{
4 Психическое развитие младших школьников: Экспериментальное психологическое исследование / под ред. В.В. Давыдова. М.: Педагогика, 1990. С. 9-10.

5 Выготский Л.С. Собр. соч. В 6 т. Т. 4. М., 1984. С. 256.

6 Леонтьев А.Н. Проблемы развития психики. М., 1981. С. $514-515$.
} 


\section{Психология и психотехника 4(55) • 2013}

Действительно, жизненный опыт показывает, что ребенок с раннего возраста в доступных ему формах жизнедеятельности объективно включается в систему общественных отношений. В общении со взрослыми и сверстниками он приобретает и обменивается разного рода информацией, испытывает различного рода влияния, учиться общаться. В этом процессе, в значительной мере не осознаваемом самим ребенком, идет формирование его личности, приобретение им собственного опыта деятельности и общения, усвоение общественных ценностей и норм: человеколюбие, способность понять и воспринять другого человека, умение сочувствовать, сопереживать, т.е. закладывается все то, что и делает человека - человеком.

Важным моментом является тот факт, что основные навыки интерпретации информации человек получает в процессе освоения речевой деятельности, т.е. в процессе непосредственного общения с источником информации. К моменту формирования стойких речевых навыков основные приемы интерпретации информации алгоритмизируются и фиксируются в подсознании, становясь когнитивными стереотипами и обеспечивая удовлетворение коммуникационных потребностей на уровне решения практических задач повседневного бытия - человек обычно способен определить, чего он хочет, и чего хотят от него. В ситуации живого диалога прагматические установки его участников достаточно легко взаимно распознаются или реконструируются при взаимном знании контекста. К непосредственным формам общения человек приспособлен биологически, т.е. природой в нем предопределена способность к освоению подобной коммуникации. Опосредованным формам общения (чтению, письму) приходится учиться - это уже социальные качества, для приобретения которых необходимо совершать определенное насилие над природной данностью. В этом смысле в возрасте примерно от 3 до 6 лет развитие ребенка происходит в подготовке к освоению именно этих видов деятельности. Сохраняется ли привычная для человека схема коммуникации в компьютеризированном социальном взаимодействии, когда источником информации оказывается не реальный человек, а информационный квазисубъект? Возможно ли в этом случае полноценная подготовка к обучению ребенка устной и письменной речи?

В идеальном варианте реального общения, при выполнении определенных условий (например, соблюдения постулатов речевого сотрудничества, по Г. Грайсуㄱ: речевой достаточности, конкретизации темы,

7 Грайс Г.П. Логика и речевое общение // Новое в зарубежной лингвистике. Вып. XVI. Лингвистическая прагматика. M., 1985. C. 217-236. отказа от лжи и двусмысленности и т.д.) цели общения четко оговариваются, и после обмена информацией фиксируется их достижение. Однако даже в реальном общении ни одно из этих условий обычно в полной мере не выполняется. Этот факт говорит о том, что реальная человеческая речь неимоверно сложна и многозначна. Чего же ждать от общения в компьютеризированном информационном взаимодействии ребенка дошкольного возраста? Способен ли он справиться с интерпретацией информации, продуцируемой в информационной реальности?

Как было показано выше, ведущей деятельностью в период идентификации является игра. В литературе по детской психологии и педагогике имеется достаточно богатый материал, посвященный изучению познавательных и развивающих игр для детей дошкольного возраста. Причем внимание уделяется сенсомоторной деятельности, являющейся основой для психического развития детей, развития творческих и интеллектуальных способностей, подготовкой к развитию навыков письменной речи.

Как известно, сенсомоторика развивается в процессе рисования, лепки, аппликации, конструирования и т.д. Сегодня все активнее на смену карандашу и бумаге, кубикам и мозаике, приходят компьютерные программы. Они очень привлекательны для ребенка, так как красочны, музыкальны, включают элементы мультипликации, интерактивны. Однако для их использования требуется умение и понимание логики компьютерных операций и их последовательности, из которой и складывается игровое действие. Получается, что участие в информационно-компьютерном взаимодействии требует от ребенка наличия определенных интеллектуальных навыков. Но известно, что они не могут быть сформированы без определенного уровня развития сенсомоторных навыков. Значит для столь раннего обучения ребенка овладению навыками информационно-компьютерного взаимодействия необходимо достаточно серьезное вмешательство в последовательность его психического развития. Что по данному поводу говорят психологи-практики? «Можно считать, - пишет И.Г. Белавина, - что дети, которые сейчас занимаются в КИК (компьютерно-игровой комплекс), - а это дети в возрасте от 5 до 7 лет, - не подготовлены к целенаправленной игре с компьютером. Без этапа специально организованной подготовки ребенка, без целенаправленного формирования представления о том, что можно делать с компьютером, мы наблюдаем «кнопочную игру», бедную по содержанию, быстро затухающую, не развивающуюся...четкость, определенность представлений ребенка о компьютере формируется очень медленно, постепенно, не сразу. Практически 


\section{Горизонты психологии}

это происходит лишь к концу первого года посещения КИК, при еженедельных сеансах длительностью не более 15 минут» ${ }^{8}$. Получается, что ребенку в столь раннем возрасте оказывается неимоверно сложным освоение компьютерной деятельности. Более того, в возрасте 3-4 лет, а именно его психологи назвали подготовительным этапом к освоению компьютера, ему для развития психических способностей необходима деятельность с реальными предметами, а не с их информационными копиями. Однако, как видно из выше приведенной цитаты, детей ожидает планомерное насилие по обучению навыкам компьютерной деятельности, т.к. прежде чем поиграть с компьютером, необходимо как минимум год обучаться этой деятельности. Не абсурд ли это?

Допустим, что дети с 3 до 5 лет, преодолели трудности, связанные с освоением навыков компьютерных игр под давлением педагога, т.к. иначе этот процесс назвать трудно. Но, где гарантия того, что сам ребенок не будет отдавать предпочтение компьютерным играм в силу их привлекательности, а педагоги и родители смогут справиться с соблюдением ограничений, предписанных психологами? «Создатели КИК (компьютерно-игровой комплекс), - пишет И.Г. Белавина, - предполагали, что использование компьютера в качестве средства воспитания и развития творческих способностей ребенка лишь дополняет обычные занятия, не заменяя их. Компьютерные программы, входящие в комплект КИК, ориентированы на детей начиная с четвертого года жизни» ${ }^{9}$. Но это только лишь теоретические предположения, тогда как практика показывает иное. Достаточно обратиться к печальному опыту детской телемании, когда одни взрослые убеждают детей в том, что чрезмерное увлечение просмотром телевизионных передач пагубно влияет на их здоровье и психику, а другие - создают все условия для развития этой самой телемании. Следовательно, проблема корениться в самой системе, изменить которую не в силах одни лишь предостережения.

Подтверждение наших опасений мы находим в экспериментальных исследованиях, проведенных почти через десять лет после, исследований описанных выше. При исследовании влияния компьютерных игр на развитие дошкольника были сделаны следующие выводы: «Сравнительный анализ результатов диагностики показал, что наблюдается стабильная динамика в сторону повышения уровня развития понятийного (интуитивного, речевого, логического, образного) и практического мышления, тогда как уровень развития абстрактного

8 Белавина И.Г. Восприятие ребенком компьютера и компьютерных игр // Вопросы психологии. 1993. № 3. С. 69.

9 Там же. С. 63. мышления остался прежним с несущественными изменениями» ${ }^{10}$. Получается, что родовой признак человека «способность к абстрактному мышлению», отличающий его от животных и систем искусственного интеллекта, возможно, будет отставать в развитии от других форм мышления. И далее из данной работы следует: «В частности, многие дети, решая те или иные задания, вместо проговаривания предпочитают оперировать «мышью». Так, опираясь на теорию поэтапного формирования умственных действий П.Я. Гальперина, мы наблюдаем потерю одного из этапов - «внешнеречевого», на котором важным является использование речи для комментирования выполняемых учебных действий. К каким изменениям и преобразованиям познавательной сферы это приведет, покажут будущие исследования» ${ }^{11}$. Вопрос только в том, что мы снова решаем проблемы по мере их поступления. Не случится ли так, что исследования снова опоздают, и мы окажемся перед ситуацией, сложившейся в Южной Корее, где уже сегодня в возрасте до 29 лет интернет-зависимых людей оказывается 96\%. Мы думаем, что существует прямая зависимость между утратой определенных этапов при формировании умственной деятельности в информационной реальности и больной психикой, которая в этом случае формируется.

Эволюция содержания и методов социализации, как уже отмечалось, неразрывно связаны с изменением социально-экономической структуры и форм общественной деятельности людей. По мере усложнения и обогащения культуры объем передаваемых от поколения к поколению знаний, умений и навыков увеличивается, а сами способы их передачи усложняются. В результате функция социализации переходит сначала от семьи к специализированным социальным институтам, а затем, с созданием сложной компьютерной техники, появляется возможность часть функций социализации передать и ей. И этот процесс продиктован вполне объективными условиями, т.е. он закономерен и необходим. Значит, ребенок все с более раннего возраста будет вынужден начинать осваивать компьютеризированные формы общения и деятельности.

Может оказаться так, что, несмотря на принятие всевозможных мер предосторожности со стороны психологов и педагогов, в силу неуклонных законов общественного развития, информационно-компьютерное взаимодействие начнет сокращать долю предметной

10 Батенова Ю.В. Особенности развития мышления дошкольника в условиях игровой компьютерной деятельности // Психология. Журнал Высшей школы экономики. 2011. Т. 8. № 4. C. 70.

11 Там же. С. 71. 


\section{Психология и психотехника 4(55) • 2013}

деятельности за счет появления нового вида деятельности - информационной, в которой происходит оперирование информационными объектами. Психологи уже отмечают подобную тенденцию, указывая на нарушение единства «рука-глаз»: «Исключение из детской деятельности в процессе компьютерной игры этапа непосредственного обследования предмета на основе движения руки по контуру этого предмета не позволяет осуществить чисто зрительный анализ на высоком уровне» ${ }^{12}$.

В данном случае в руках ребенка оказывается не пластилин или карандаш, а клавиши и кнопки. В.А. Сухомлинский писал: «Истоки способностей и дарований детей - на кончиках их пальцев. От пальцев, образно говоря, идут тончайшие ручейки, которые питают источник творческой мысли» ${ }^{13}$. В современной литературе отсутствует в достаточном количестве исследовательский материал, который показывал бы, к чему может привести частичное или полное исчезновение данного вида деятельности в детском возрасте из-за переноса ее в сферу информационно-компьютеризированного взаимодействия. Это и понятно, т.к. оно еще «не накрыло человечество с головой». В задачу психологов и педагогов не входит столь «загоризонтальное» проектирование своей деятельности, они изучают тот материал, который имеются у них в настоящий момент. Философы, ставят подобные проблемы, но, к сожалению, пока мало обращают внимание на изучение причин их возникновения.

Если учесть, что развитие сенсомоторных способностей детей направлено на подготовку их к обучению чтению и письму, то выводы вполне очевидны. Трансформация этих видов деятельности приводит к смене методов подготовки к ней. Письменная культура на основе ручки и бумаги, вытесняясь культурой «нажатия клавиш», требует и соответственных механизмов ее освоения. Получается, что переход от таких видов деятельности как письмо и чтение к аудио-видео деятельности приводит к исчезновению необходимости развития одних навыков, и появлению необходимости развития совершенно других. Возникает вопрос: стоит ли человечеству сопротивляться грядущим переменам или необходимо им соответствовать, меняя при этом самого себя?

С данными дилеммами все чаще сталкиваются исследователи. Например, В.В. Тарасенко, анализируя антропологию Интернета, приходит к выводу, что такие

12 Обухова Л.Ф., Ткаченко С.Б. Возможности использования компьютерных игр для развития перцептивных действий // Психологическая наука и образование. 2008. № 3. С. 49-60.

13 Сухомлинский В.А. Сердце отдаю детям. Киев, 1973. С. 258. коммуникативные практики, как чтение и письмо также инвалидизированы, т.е. неестественны для человека, как и компьютерная коммуникация. На вопрос кем считать «человека кликающего» шизофреником или представителем нового типа культуры, автор выбирает второй вариант ответа ${ }^{14}$.

Как видим, с одной стороны информационнокомпьютеризированное взаимодействие способствует ускорению процесса социализации и повышению его эффективности, что оказывается необходимым условием в быстро меняющейся социальной системе, а с другой - деформирует личность. Лишив ребенка возможности ощущать любимую игрушку, листать страницы красочной книжки, слышать реальный голос родных и близких, мы погружаем его с раннего возраста в информационный мир. Хорошо известно, например, что телесный контакт родителей с ребенком незаменим ничем и никем и является одним из существеннейших факторов формирования личности человека. Более того, духовное начало в человеке произрастает только на основе усвоения определенных традиций телесной культуры. Очевидно также, что без «живых примеров» родителей и близких людей крайне затрудняется выработка моральных критериев поведения.

Итак, что касается психического развития ребенка через сенсомотороное восприятие, то механизмы информационно-компьютерной социализации, безусловно, открывают огромные возможности в развитии личности XXI в., но несет в себе и не меньшую опасность, о чем и говорилось выше. Однако этим не исчерпывается передача и усвоение социального опыта. Способы восприятия социальной информации расширяются у ребенка с возрастом, когда все активнее подключаются мышление, речь, познание и т.д. В этом случае информационно-компьютерная социализация начинает еще интенсивнее конкурировать с традиционными формами социализации. Но и в этом случае, может оказаться так, что она станет нормой, а не проблемой, т.к. именно в этом и заключается эволюция человека - он должен измениться, но в какой степени и как?

Б. Метлер-Мейбом пишет, что компьютер и телевизор ущемляют право человека на основании своего опыта объяснять свою жизнь или отражаемый им окружающий мир и наследовать коммуникативную компетентность ${ }^{15}$. Нам остается добавить только то,

\footnotetext{
14 Тарасенко В.В. Антропология Интернет: самоорганизация «человека кликающего» // Общественные науки и современность. 2000. № 5. С. 116.

15 Метлер-Мейбом Б. Социальные цены в информационном обществе: Размышления о коммуникативной экологии // Информационная революция: наука, экономика, технология. М.: ИНИОН РАН, 1995. С. 162.
} 


\section{Горизонты психологии}

что ущемление этих прав оказывает не сам компьютер, а именно информационно-компьютеризированное взаимодействие, в которое вовлекается ребенок с раннего детства. В процессе социализации происходит формирование двух весьма существенных социальнопсихологических установок, из которых в дальнейшем и складывается сущность человека. Это: чувство общности и единения с себе подобными - «Мы», что снимает комплекс отчужденности, оторванности и замкнутости и чувство индивидуальности, т.е. способности к осмыслению собственного «Я», которое растворяется в «Мы». И все это происходит благодаря тем взаимодействиям людей друг с другом, которые и называются общественными отношениями. Вывод учеными и педагогами сделан давно: человек становится человеком только в человеческом обществе, благодаря тем общественным отношениям, в которые он вступает с первых дней своей жизни после рождения. Возможно, этот процесс начинается и до рождения, но это уже другой разговор и он требует самостоятельного исследования.

Уже неоднократно отмечалось, что в становлении личности XXI в. большую роль стали играть компьютеры, которые, чаще всего, становятся не только посредниками между ребенком и обществом, но и субъектом социализации, постепенно вытесняя из системы социализации разнообразные образовательные институты, превращаясь в универсальный механизм социализации. В связи с этим, возникает исключительной важности вопрос: «Не повлияет ли информационно-компьютеризированное взаимодействие на чувство общности?».

Компьютерные программы могут достигать сегодня такого высокого уровня, что образ, создаваемый ими, будет принят ребенком за естественное и живое существо, через которое он и будет воспринимать окружающий мир. Но не стоит забывать при этом, что компьютерные программы - это только особым образом сформулированный и использованный опыт человека. В кругу сверстников, в процессе общения, у детей постоянно возникают неадекватные и неординарные ситуации, из которых они чаще всего сами находят выход. Может ли компьютерная программа предложить ребенку подобную модель поведения? На этот вопрос исследователи отвечают положительно. Однако она все равно будет генерировать готовые ситуации и соответствующие решения. Ребенок в этом случае лишиться и самостоятельности, и активности в принятии собственных решений, а ведь именно этими чертами и характеризуется человек как субъект деятельности. Воспитанный информационным квазисубъектом человек, при общении с реальными людьми, вряд ли, сможет применить полученные знания в реальной жизни. Это объясняется тем, что сущность человека, в полном объеме, несводима к чисто рациональному мышлению и целесообразной деятельности. Помимо сознания в человеке есть еще и подсознательное - нечто неподдающееся формализации и компьютерному программированию.

Таким образом, с одной стороны, информационная социализация личности - неизбежна в информационном обществе, она необходима для развития техники, технологии, улучшения качества жизни и т.д. С другой стороны, сверхрационализация опасна для становления личности, т.е. человеческого начала, поскольку она разрушает баланс сознательного и подсознательного, постепенно утверждая приоритет первого над вторым.

Выше уже говорилось о том, что в период идентификации у детей особенно развито чувственное восприятие. Оставляя их наедине с компьютером, мы обрекаем маленького человека на восприятие мира не эмоциями и чувствами, а разумом, который еще не способен правильно оценивать ситуацию. Даже для взрослого человека информация с экрана компьютера воспринимается не всегда легко и правильно, потому что это требует особой работы мозга и уже сложившегося миропонимания, умения работать с информацией. Происходит как бы удвоение мира: «Я» со своим субъективным мироощущением и «Я'» - компьютерный квазисубъект, существующий независимо от меня, навязывающий моему «Я» информацию, как бы из «вторых рук». При этом нарушается биологически и психологически детерминированный способ усвоения информации через непосредственное взаимодействие людей друг с другом. В психике формируется дематериализованный мир, заменяющий реальный мир, мир, к взаимодействию с которым приспособлены и психика, и тело человека.

Как было показано выше, основу развития основных навыков человеческой деятельности в период идентификации составляет не только игра, но и коммуникативная деятельность. Именно в игре, ребенок, выполняя разные роли, которые являются как бы мини социальными ролями общества, готовиться к взрослой жизни. В детских играх присутствует и жестокость, и агрессивность, свойственные человеку как биологическому существу. Если эти качества проявляются в процессе игры со сверстниками, то, как правило, они и гасятся ими же или взрослыми. Совсем иное дело, когда ребенок играет в компьютерные игры. Здесь все иначе. Никто не даст сдачи, никто не остановит, никто не объяснит, что данная модель поведения не принята в той или иной ситуации. Скорее наоборот, чтобы завлечь ребенка игрой, создатели делают ее наиболее кровожадной. Таким образом, компьютерные игры способны поощрять в человеке все его негативные стороны, более того, даже развивать их. 


\section{Психология и психотехника 4(55) • 2013}

Вывод, вероятно, один: пока мы не научимся снимать негативные последствия информационно-компьютеризированного взаимодействия, нельзя включать его в социализацию личности на этапе идентификации. На этом этапе социализацию следует проводить «дедовским» способом, т.е. через непосредственное общение: человек-человек. Только это (пока) научает ребенка сопереживать, сострадать, сочувствовать, отличать хорошее от плохого, ориентироваться в моделях поведения, используя заложенные в процессе воспитания ценностные установки. Иначе, возникает опасность того, что ребенок будет идентифицировать себя не с близкими людьми или с человеческим обществом, а с компьютерными квазисубъектами. Такой квазисубъект будет служить ребенку образцом для подражания. Появиться проблема, аналогичная проблеме «маугли», с той лишь разницей, что дети будут воспитаны не в волчьей стае, а в «стае информационных квазисубъектов». На вопрос, который задает себе ребенок после завершения процесса идентификации «Кто Я?», возможно, мы будем слышать не привычные ответы «Я человек», a, скорее всего - «Я - компьютер» или «Я - робот», или что-нибудь в этом роде. Поэтому так важно, чтобы первичная социализация в большей степени проходила у ребенка в обществе себе подобных, а не ограничивалась рамками информационно-компьютеризированного взаимодействия. Это важно еще и потому, что традиционные методы социализации, подразумевающие воспитание на народных сказках, баснях, песнях, обычаях формирует и социальный иммунитет ребенка, готовит его к жизни в том обществе, где ему предстоит и дальше развиваться, уметь выходить из конфликтов между такими же людьми, как и он сам.

Конечно же, сегодня компьютер уже нельзя совсем исключать из процесса социального взаимодействия, а, следовательно, и социализации. Он уже играет свою роль ускорителя социализации личности. Но для этого необходим теоретический анализ с использованием результатов исследования социальной философии, педагогики, психологии и социальной психологии детей данного возраста. Наверное, найдутся сторонники того мнения, что в принципе, утратив потребность в наличии самого реального мира, человек в будущем перестанет нуждаться и в формировании способности общаться, и в идентифицировании себя с человеческим родом. А.М. Горький говорил о том, что в каждом человеке скрыт бубенчик, и если его затронуть, человек зазвучит всем лучшим, что в нем есть. Лишая ребенка возможности учиться общаться в кругу себе подобных, мы можем оказаться перед тем фактом, когда не будет нужды затрагивать эти самые бубенчики, потому что их просто не останется. И, если это станет нормой для всего человечества, то, конечно, не стоит и беспокоиться по этому поводу.

Если учесть, что человека можно уничтожить физически, биологически, психологически, и социально, то, на какое уничтожение направлено вовлечение «человеческого начала» в процесс информационно-компьютеризированного взаимодействия? Если трансформации подвергается все уровни, то каков будет результат?

В данной статье мы проанализировали возможные последствия информационно-компьютерной социализации на самом раннем этапе становления личности и пришли к выводам, что она неизбежно влечет за собой трансформацию человеческой сущности. Если помнить высказывание знаменитых педагогов о том, что ребенка можно воспитать до 5 лет, а после 5 только перевоспитывать, то становится очевидным - идентификация, прошедшая в информационно-компьютеризированном взаимодействии с необходимостью предполагает в нем и индивидуализацию. Но и дальнейшая социализация на базе информационно-компьютеризированного взаимодействия - это путь к следующему этапу деформации личностных качеств, а значит новый стресс. Человечество сделало свой выбор и продолжает идти по пути эволюции, программу которой создает не природа, а он сам.

В результате исследования идентификации человека в информационной реальности, мы пришли к следующему:

1. Информационно-компьютерная социализация личности основывается на информационно-компьютерном взаимодействии, которое происходит в поле информационной реальности. Спецификой такого вида социального взаимодействия является информационная форма его составляющих: субъекта, объекта, средств и т.д. При этом появляется новая форма субъектности - информационный квазисубъект - информационный объект, способный исполнять роль субъекта деятельности, общения и коммуникации.

2. Идентификация в информационно-компьютерной социализации имеет как положительные, так и отрицательные стороны. С одной стороны, происходит уплотнение социального времени, что становится необходимым фактором для адаптации индивида к быстро меняющимся социальным условиям. С другой стороны, это уплотнение происходит в большей степени за счет сокращения доли непосредственного общения, что оказывает пагубное влияние на формирование человеческой психики.

3. При информационно-компьютерной идентификации возможно частичное или полное вытеснение реального субъекта социализации и замены его на квазисубъекта. При этом разрушается реаль- 


\section{Горизонты психологии}

ное соседство людей, к которому приспособлен человеческий организм биологически, физически и психически за всю многовековую историю своего развития. Результатом такой идентификации может стать формирование индивида идентифицирующего себя не с человеческим обществом, а с компьютерными квазисубъектами.

Таким образом, идентификация в информационно-компьютерной социализации может привести к трансформации основных форм мышления человека, а, следовательно, к изменению его психических особенностей, одна из которых становится уже сегодня бедой высокотехнологичных стран - поголовная зависимость молодых людей от информационно-компьютерных форм взаимодействия. Основная причина - замена реального субъекта социализации на информационные квазисубъекты, способные программировать личность, а не формировать ее.

\section{Список литературь:}

1. Батенова Ю.В. Особенности развития мышления дошкольника в условиях игровой компьютерной деятельности / Ю.В. Батенова // Психология. Журнал Высшей школы экономики. 2011. Т. 8. № 4. С. 59-72.

2. Войскунский А.Е. Методологические аспекты зависимости от Интернета: зарубежные исследования / A.Е. Войскунский // Интернет-зависимость: психологическая природа и динамика развития / Под ред. А.Е. Войскунского. М.: Акрополь, 2009. С. 101-111.

3. Войскунский А.Е. Психология и Интернет / А.Е. Войскунский. М.: Акрополь, 2010. 439 с.

4. Грязнова Е.В. Информационная реальность и социум / Е.В. Грязнова. Н. Новгород: ННГАСУ, 2010. 203 с.

5. Мураткина Ю.Н. Взаимосвязь компьютерной зависимости и совладающего поведения подростков: автореф. дисс. ... канд. психол. наук: 19.00.07. Сургут, 2010. 23 с.

6. Прихожан А.М. Влияние электронной информационной среды на развитие личности детей младшего школьного возраста [Электронный ресурс] // Психологические исследования: Электронный научный журнал. 2010. № 1 (9). (URL: http:// psystudy.ru).

7. Цой Н.А. Информационная политика государства и феномен Интернет зависимости в России и Китае / Н.А. Цой // Вестник Российского университета дружбы народов. Серия Социология. 2010. № 4. С. 5-16.

8. Young K.S., Abreu C.N. Introduction // K.S. Young, C.N. Abreu (eds.). Internet addiction: A handbook and guide to evaluation and treatment. Hoboken, N.J.: John Wiley \& Sons, 2011.

\section{References (transliteration):}

1. Batenova, Yu.V. Osobennosti razvitiya myshleniya doshkol'nika v usloviyakh igrovoy komp'yuternoy deyatel'nosti / Yu.V. Batenova // Psikhologiya. Zhurnal Vysshey shkoly ekonomiki. 2011. T. 8. № 4. S. 59-72.

2. Voyskunskiy, A.E. Metodologicheskie aspekty zavisimosti ot Interneta: zarubezhnye issledovaniya / A.E. Voyskunskiy // Internet zavisimost': psikhologicheskaya priroda i dinamika razvitiya / Pod red. A.E. Voyskunskogo. M.: Akropol', 2009. S. 101-111.

3. Voyskunskiy, A.E. Psikhologiya i Internet / A.E. Voyskunskiy. M.: Akropol', 2010. 439 s.

4. Gryaznova, E.V. Informatsionnaya real'nost' i sotsium / E.V. Gryaznova. N. Novgorod: NNGASU, 2010. 203 s.

5. Muratkina, Yu. N. Vzaimosvyaz' komp'yuternoy zavisimosti i sovladayushchego povedeniya podrostkov: avtoref. diss.... kand. psikhol. nauk: 19.00.07. Surgut, 2010. 23 s.

6. Prikhozhan, A.M. Vliyanie elektronnoy informatsionnoy sredy na razvitie lichnosti detey mladshego shkol'nogo vozrasta [Elektronnyy resurs] // Psikhologicheskie issledovaniya: Elektronnyy nauchyy zhurnal. 2010. № 1 (9). (URL: http:// psystudy.ru).

7. Tsoy, N.A. Informatsionnaya politika gosudarstva i fenomen Internet zavisimosti v Rossii i Kitae / N.A. Tsoy // Vestnik Rossiyskogo universiteta druzhby narodov. Seriya Sotsiologiya. 2010. № 4. S. 5-16.

8. Young K.S., Abreu C.N. Introduction // K.S. Young, C.N. Abreu (eds.). Internet addiction: A handbook and guide to evaluation and treatment. Hoboken, N.J.: John Wiley \& Sons, 2011. 